УДК 633.432; 577.15

\title{
Optimization of the enzymatic process parameters for increase of carrot juice yield
}

\author{
E. N. ZELENKOVA ${ }^{1}, P h$. $D$. Z. E. YEGOROVA ${ }^{2}$ \\ 1'zelenkovaelenanik@gmail.com, ${ }^{2}$ egorovaze@tut.by \\ Belarusian State Technological University, Minsk, Belarus
}

The process of enzymatic hydrolysis of carrot pulp was investigated for increase of carrot juice yield and carotene content in it. It was revealed that enzymatic preparations Pectinex BEXXL, Vegazim P and Vegazim P-CS demonstrated high efficacy in juice yield and Vegazim $M$ and Vegazim P-CS - in carotene content. Vegazim P-CS was chosen from seven enzyme preparations according to the aggregate of estimated characteristics: carrot juice yield was equal to $71.6 \%$ and carotene content - $4.83 \mathrm{mg} / 100 \mathrm{~g}$. It is more $18,2 \%$ and in 1.7 times respectively as compared with the control. The multivariate experiment to optimize the enzyme treatment of carrot pulp was designed and implemented. The resulting mathematical second-order model reflects a dependence of juice yield from the enzyme concentration, temperature and incubation time. Increase of juice yield was shown when enzyme concentration was raising up to $\sim 0.3 \mathrm{ml} / 1000 \mathrm{~g}$ of carrot pulp. Further concentration growth had led to decrease of the response due to thinning pulp and deterioration of juice extraction, which is in agreement with experimental data. Increasing the temperature and incubation time of enzymatic hydrolysis greater than $65^{\circ} \mathrm{C}$ and $120 \mathrm{~min}$ haven't led to a further increase in juice yield too. The optimal parameters were established: temperature $-\sim 52{ }^{\circ} \mathrm{C}$, incubation time - $85 \mathrm{~min}$, concentration of Vegazim P-CS $\sim 0,3 \mathrm{ml} / 1000 \mathrm{~g}$ of carrot pulp. The obtained data demonstrate differences in the action of enzyme preparations, show feasibility of optimizing the enzymatic treatment parameters for a particular enzyme preparation according to the manufacturer's goals.

Keywords: enzymatic hydrolysis, parameters, optimization, carrot juice.

\section{Article info:}

Received 18/03/2019, accepted 08/07/2019

DOI: $10.17586 / 1606-4313-2019-18-3-45-50$

Article in English

For citation:

Zelenkova E. N. Yegorova Z. E. Optimization of the enzymatic process parameters for increase of carrot juice yield. Vestnik Mezhdunarodnoi akademii kholoda. 2019. No 3. p. 45-50

\section{Оптимизация параметров ферментативного гидролиза для увеличения выхода морковного сока}

\author{
Е. Н. ЗЕЛЕНКОВА', канд. техн. наук 3. Е. ЕГОРОВА ${ }^{2}$ \\ ${ }^{1}$ zelenkovaelenanik@gmail.com, ${ }^{2}$ egorovaze@tut.by \\ Белорусский государственный технологический университет
}

\begin{abstract}
Исследован процесс ферментолиза морковной мезги для увеличения выхода морковного сока и содержания каротина в нем. Выявлено, что ферментные препараты Pectinex BEXXL, Vegazim Р и Vegazim P-CS продемонстрировали высокую эффективность по показателю выход сока, а Vegazim M и Vegazim P-CS - по показателю содержание каротина. По совокупности оцененных показателей, из семи ферментных препаратов был выбран Vеgаzіт Р-CS, обработка которым позволила получить выход сока, равный 71,6\% и содержание каротина в нем - 4,83 мг/100 2. Это больще на 18,2\% и в 1,7 раз соответственно по сравнению с контролем (без обработки). Был спланирован и реализован многофакторный эксперимент для оптимизации процесса ферментолиза морковной мезги. Полученная математическая модель второго порядка отражает зависимость выхода сока от концентрации фермента, температуры и продолжительности обработки. Показано увеличение выхода сока при возрастании концентрации фермента до значений $\sim 0,3$ мл/1000 г морковной массы. Дальнейшее повышение дозировки приводило к снижению значений отклика из-за разжижения мезги и ухудиения сокоотдачи, что согласуется с экспериментальными данными. Увеличение температуры и продолжстельности ферментолиза больще значений $65^{\circ} \mathrm{C}$ и 120 мин также не приводило к дальнейшему повышению выхода сока. Установлены оптимальные значения параметров: температура $\sim 52{ }^{\circ}$, время инкубации $\sim 85$ мин, концентрация препарата Vеgаzім P-CS 〜0,3 мл/1000 г морковной массы. Полученные данные демонстрируют различия в действии ферментных препаратов, показывают целесообразность оптимизации режимов ферментолиза для конкретного ферментного препарата в соответствии с целями производтеля.
\end{abstract}

Ключевые слова: ферментативный гидролиз, параметры, оптимизация, морковный сок. 


\section{Информация о статье:}

Поступила в редакцию 18.03.2019, принята к печати 08.07.2019

DOI: $10.17586 / 1606-4313-2019-18-3-45-50$

Язык статьи - английский

\section{Ссылка для цитирования:}

Zelenkova E. N. Yegorova Z. E. Optimization of the enzymatic process parameters for increase of carrot juice yield. // Вестник Международной академии холода. 2019. № 3. С. 45-50.

\section{Introduction}

The enzymatic hydrolysis is frequently used in vegetable juices production. It is known that enzymes allow to improve the technological properties of pulp, facilitate the recovery and micronutrients extraction. As a result, finished products have high quality characteristics and nutritional value.

At present time, action of amylolytic, pectolytic, proteolytic, cellulolytic enzymes on fruit and vegetable raw materials has been studied. Mono- as well as polyenzyme preparations may be used in juice production. They affect the juice yield, acidity, solid content and other physical and chemical characteristics, and also can improve the content of active components that are beneficial to human's organism [1-8].

Carrot juice has a high nutritional value and is rich in biologically active micronutrients, such as $\alpha$-, $\beta$-carotene, lutein [9]. In production of carrot juice, as is known, enzymatic treatment of carrot pulp improve juice yield, amount of soluble solids, content of carotenoids [10-13].

Numerous researches (Demir N., Sun Y., Liao H., Li J. Y.) have been devoted to study the influence of pre-treatment of grated carrot with enzymes on juice characteristics. The role of pectinase have been investigated. According to the work Demir N. et al. [11], carrot juice yield have been increased up to $90.43 \pm 0.47 \%$ when enzyme preparation Pectinex Ultra SP-L (pectinase) by Novozymes (Denmark) was used. For comparison, juice yield in the control sample was $59.9 \pm$ $0.81 \%$. At the same time, researchers at the China Agricultural University carried out an experiment in which Pectinex Smash XXL [14] was used for maceration of carrot pulp. As a result, the juice yield increased by $20 \%$ (from $44.92 \%$ up to $64.40 \%$ ). A year earlier (in 2006), Sun Y. et al. [12] received similar results on the yield of carrot juice $(63.5 \%)$ using the same enzyme preparation Pectinex Smash XXL. This preparation proved to be better than Pectinex Ultra SP-L, Pectinase FNP1 and cellulose FNC-1, and was recommended by the authors for the production of carrot juice. The effectiveness of pectolytic enzymes was also confirmed by Li Juan $\mathrm{Yu}$ [3]. Pectinex $3 \mathrm{XL}$ (pectinase) allowed to increase the carrot juice yield by $31 \%$ as compared to control. When the same enzyme preparation in combination with Celluclast $1.5 \mathrm{~L}$ (cellulase) and Novozyme 188 (b-glucosidase) was used for enzymatic hydrolysis of carrot pulp, juice yield was increased by $30 \%$, which was equal to $76 \%$. At the same time, authors obtained a very low yield of carrot juice (at a level of 30-40\%) when only cellulolytic enzymes were used. V. Khandare et al. [1] have shown that pectinase-assisted processing significantly improved the juice yield from black carrot (an overall increase of $33 \%$ ).

Thus, analysis of literature showed that pectolytic enzymes were the most important enzymes for enhancing juice recovery $[1,3,10-17$,$] .$
On the other hand, it is known that the increase in the content of carotene and other micronutrients, as well as soluble solids in carrot juice, is promoted by cellulolytic enzymes. They destroy cell walls and provide the release of nutrients from cells. The combined use of pectolytic and cellulolytic enzymes enhances their pectolytic and cellulolytic activity through a synergetic effect [8]. Thus, combination of different enzymes affords to achieve good results not only in the yield of carrot juice, but also in improving its organoleptic characteristics (color, taste, appearance). In this regard, frequently producers use a mixture of enzymes with polyenzyme complex, which biocatalytically affects multicomponent substrates of vegetable raw materials.

For example, researchers Vora H. M. [15], Sun Y. [12], Sharma A. K. [13], Chadha R. [16], İnci Çinar [18] evaluated the effect of different enzymes on raw materials. So, it was shown by Vora H. M. et al. [15] that content of $\beta$-carotene in the juice increased substantially when enzyme preparations under the trade name Rohament PL and Rohament MAX, the complex of which includes pectinase, hemicellulase, cellulase and polygalacturonase, were used. At the same time, yield of the desired product was also high $-72.4 \%$. Sun Y. et al. [12] enhanced the content of $\beta$-carotene to $54.2 \mathrm{mg} / \mathrm{kg}$ in juice treated with pectolytic and cellulose enzymes, as compared to control $-40.1 \mathrm{mg} / \mathrm{kg}$. According to the work of Li Juan Yu et al. [3], the joint use of enzyme preparations of pectinase, cellulase and $\beta$-glucosidase made it possible to improve the qualitative characteristics of carrot juice by $\beta$-carotene content 1.6 times $(33.71 \mathrm{mg} / \mathrm{kg}$ compared to control of $21.39 \mathrm{mg} / \mathrm{kg}$ ). The amount of soluble solids was $8.93^{\circ}$ Brix ( $22 \%$ higher than the control sample). Tingting Ma et al. [19, 20] have demonstrated that single enzyme treatment or mixed enzyme treatment with different orders of addition could significantly raise the contents of the three carotenoids in carrot juice ( $\alpha$-carotene, $\beta$-carotene and lutein). However, the use of pectinase and cellulase at the same time exhibited an antagonistic effect.

As is known, it is necessary to apply appropriate biocatalysis regimes to obtain the maximum effect from the use of enzymes. Thus, Sharma et al. (2005) obtained a maximum juice yield of $74.03 \%$ for the following parameters: enzyme concentration $210 \mathrm{mg} / \mathrm{kg}$, incubation time $130 \mathrm{~min}$, and temperature $47^{\circ} \mathrm{C}$. Similar result (71.5\%) was obtained by Chadha et al. [16]. However, the authors used pre-treatment with pectolytic and cellulolytic enzymes under the regime: concentration $364 \mathrm{mg} / \mathrm{kg}$, temperature $51{ }^{\circ} \mathrm{C}$, incubation time $79 \mathrm{~min}$. According to the scientific work of Li Juan Yu et al. [3], the most effective condition to improve carrot juice yield (up to $76 \%$ ) was the combination of pectolytic and cellulolytic enzymes. The enzymatic treatment was carried out at $50^{\circ} \mathrm{C}$ and $\mathrm{pH} 4.0$ for $90 \mathrm{~min}$. Total enzyme concentration was 
equivalent to $0.3 \mathrm{~g} / \mathrm{kg}$ of matter. Effectiveness of such conditions (temperature $50-55^{\circ} \mathrm{C}$, incubation time $90 \mathrm{~min}$ ) was confirmed by earlier work Vora H. M. et al. [15]. But enzyme concentration was $150 \mathrm{mg}$ per $\mathrm{kg}$ carrot. The combined effect of pectolytic and cellulolytic enzymes was studied too by Gat Y. and Kaur P. [2]. The maximum possible juice yield, total soluble solids, color and minimum viscosity of carrot juice were obtained under optimal conditions for enzyme concentration, Pectolytic: Cellulolytic enzyme ratio and incubation time: $120.00 \mathrm{mg} / \mathrm{kg}$ carrot, 4:6 and 119.99 minutes, respectively.

From presented review it is clear that the choice of enzyme preparations, as well as the choice of incubation parameters, is a difficult task which must be solved within the framework of a specific product, according to the goal. Therefore, the purpose of this work was to select enzyme preparations for the production of carrot juice and optimize the parameters of enzymatic process for increase of juice yield.

\section{Materials and methods}

Carrot roots of the cultivar Flam were used in the experiment. Characteristics of the enzyme preparations are shown in Table 1.

Carrot juice was obtained in laboratory conditions, modeling the technological process. Carrots were washed, dried, peeled and milled. Further carrot pulp was heated with a flowing steam and cooled. Enzymes were added, enzymatic process and juice extraction were carried out.

At the first stage of the research, it was necessary to select an enzyme preparation that improved the qualitative characteristics of carrot juice to a greater extent. For the comparative analysis of enzymes the following criteria were used: yield of the target product, content of carotene. Juice yield was calculated as the ratio of juice weight to the mass of pulp and expressed as a percentage. Content of carotene was determined by a standardized procedure (State standard 8756.22-80. "Products processing fruits and vegetables. Method for the determination of carotene"). At this stage of the study, the same average regimes of fermentolysis were chosen, in which all the evaluated samples show a significant degree of activity: temperature $-50{ }^{\circ} \mathrm{C}$, incubation time -
$30 \mathrm{~min}$. Concentration of introduced enzyme preparations was selected according to the manufacturer's recommendations (average value of interval was used).

At the second stage of the study, the enzymatic process parameters were optimized for the enzyme which showed the best results at the first stage. The juice yield (Y) was used as optimization criterion. A centrally-compositional rotatable plan was chosen, because it allows to ensure equal accuracy of response forecasting in all points equally spaced from the center of plan. $[13,21,22]$

It is generally known that enzymes are active in the temperature range from 15 to $70{ }^{\circ} \mathrm{C}$ : below $15^{\circ} \mathrm{C}$ the activity is maintained, but the reaction rate is significantly reduced, which should be compensated by increasing the concentration; above $70{ }^{\circ} \mathrm{C}$ the enzyme is not active. The optimum temperature for pectolytic and cellulolytic enzymes produced by cultures of the genus Aspergillus is $25-65^{\circ} \mathrm{C}$. Therefore, this range of temperatures was chosen by the authors for investigation with a central point of $45^{\circ} \mathrm{C}\left(x_{1}\right)$.

The time of enzymatic treatment in juice production usually varies from 30 min to 4 hours. Longer exposure, as practice shows, does not lead to further improvement in the characteristics of the pulp. Incubation time for more than two hours is used at low concentrations of enzymes, or at low temperatures. In this connection, an interval of 30-120 min with a center of $75 \min \left(x_{2}\right)$ was analyzed.

The manufacturer's recommended concentration of Vegazim P-CS is $70-250 \mathrm{ml} / \mathrm{t}$ of pulp. However, on the other hand, the dosage of enzyme preparations used for the processing of vegetable pulp covers a wide range of 30$600 \mathrm{ml} / \mathrm{t}$ of pulp. Considering this, the authors extended the range of concentration to $100-500 \mathrm{ml} / \mathrm{t}$ of pulp $\left(x_{3}\right)$. The central point was $300 \mathrm{ml} / \mathrm{t}$.

\section{Results and discussion}

At the first stage of the research, enzyme preparation that allows improving the qualitative characteristics of carrot juice had been chosen. For this purpose, two criteria were evaluated: juice yield, content of carotene. The results are shown in Fig. 1.

Due to different nature of the characteristics being estimated, results were calculated as the ratio of actual data

Characteristics of enzyme preparations

Table 1

\begin{tabular}{|c|c|c|c|}
\hline $\begin{array}{c}\text { Trade name of enzyme preparation, } \\
\text { manufacturer }\end{array}$ & $\begin{array}{c}\text { Composition of the enzyme } \\
\text { preparation }\end{array}$ & $\begin{array}{c}\text { Treatment parameters: temperature, }{ }^{\circ} \mathrm{C} / \\
\text { incubation time, min }\end{array}$ & $\begin{array}{c}\text { Recommended concentration, } \\
\mathrm{ml} / 1000 \mathrm{~kg} \text { of pulp }\end{array}$ \\
\hline $\begin{array}{c}\text { Pectinex 5XL, Novozymes } \\
\text { (Denmark) }\end{array}$ & $\begin{array}{c}\text { Pectinase, hemicellulase, } \\
\text { cellulase, arabanase }\end{array}$ & $(15-55) /(60-240)$ & $30-400$ \\
\hline $\begin{array}{c}\text { Pectinex BE XXL, Novozymes } \\
\text { (Denmark) }\end{array}$ & $\begin{array}{c}\text { Pectinase, hemicellulase, } \\
\text { cellulase, arabanase }\end{array}$ & $(15-55) /(60-240)$ & $40-200$ \\
\hline $\begin{array}{c}\text { Pectinex BE Color, Novozymes } \\
\text { (Denmark) }\end{array}$ & Polygalacturonase, pectin lyase & $(15-55) /(60-120)$ & $150-400$ \\
\hline $\begin{array}{c}\text { Vegazim P, Erbsloh } \\
\text { (Germany) }\end{array}$ & Pectinase & $(15-55) /(30-120)$ & $75-200$ \\
\hline $\begin{array}{c}\text { Vegazim HC, Erbsloh } \\
\text { (Germany) }\end{array}$ & Hemicellulase, C1- cellulase & $200-600$ \\
\hline $\begin{array}{c}\text { Vegazim M, Erbsloh } \\
\text { (Germany) }\end{array}$ & Pectinase, polygalacturonase & $(15-55) /(30-120)$ & $150-500$ \\
\hline $\begin{array}{c}\text { Vegazim P-CS, Erbsloh } \\
\text { (Germany) }\end{array}$ & Pectinase & $(15-55) /(30-120)$ & $70-250$ \\
\hline
\end{tabular}




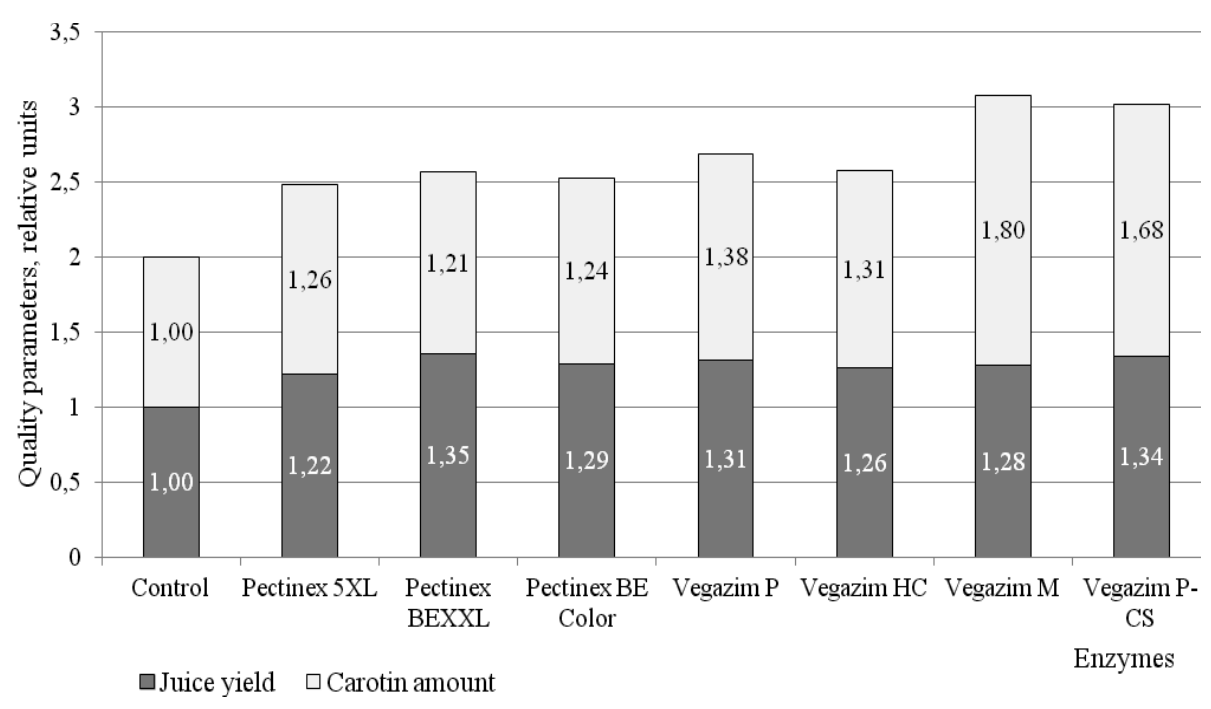

Fig. 1. Quality characteristics of carrot juice obtained using various enzyme complexes

to the reference values obtained for carrot juice without enzymatic pre-treatment. Results are presented in relative units.

Obtained results demonstrated the effectiveness of biocatalysis to increase the carrot juice yield. As can be seen from the diagram, polyenzyme complexes under the trade name Pectinex BEXXL, Vegazim P and Vegazim P-CS allow to obtain the highest yield of the target product: $72.3 ; 70.1$ and $71.6 \%$, respectively, which exceeds

Yield of carrot juice at different parameters of enzymatic treatment and result of verification of the regression equation adequacy

\begin{tabular}{|c|c|c|c|c|}
\hline \multirow{2}{*}{ Experiment № } & \multicolumn{3}{|c|}{ Coded variable } & \multirow{2}{*}{$\begin{array}{c}\text { Response } \\
y, \%\end{array}$} \\
\hline & $x_{1}$ & $x_{2}$ & $x_{3}$ & \\
\hline 1 & -1 & -1 & -1 & 54,7 \\
\hline 2 & 1 & -1 & -1 & 70,1 \\
\hline 3 & -1 & 1 & -1 & 62,6 \\
\hline 4 & 1 & 1 & -1 & 70,6 \\
\hline 5 & -1 & -1 & 1 & 61,3 \\
\hline 6 & 1 & -1 & 1 & 68,8 \\
\hline 7 & -1 & 1 & 1 & 67,1 \\
\hline 8 & 1 & 1 & 1 & 66,4 \\
\hline 9 & 1,682 & 0 & 0 & 68,0 \\
\hline 10 & $-1,682$ & 0 & 0 & 55,8 \\
\hline 11 & 0 & 1,682 & 0 & 71,1 \\
\hline 12 & 0 & $-1,682$ & 0 & 61,4 \\
\hline 13 & 0 & 0 & 1,682 & 63,9 \\
\hline 14 & 0 & 0 & $-1,682$ & 58,8 \\
\hline 15 & 0 & 0 & 0 & 78,1 \\
\hline 16 & 0 & 0 & 0 & 75,5 \\
\hline 17 & 0 & 0 & 0 & 77,0 \\
\hline 18 & 0 & 0 & 0 & 75,7 \\
\hline 19 & 0 & 0 & 0 & 74,3 \\
\hline 20 & 0 & 0 & 0 & 75,3 \\
\hline \multicolumn{5}{|c|}{ Estimation of model adequacy. Fisher's criterion } \\
\hline $\mathrm{F}_{\mathrm{c}}$ & 2,23 & & & \\
\hline $\mathrm{F}_{\mathrm{t}}$ & 2,66 & & adequa & \\
\hline
\end{tabular}

the control value by $18.9 ; 16.7$ and $18.2 \%$. These results are corresponded to the data of Demir N. et. al. [10, 11], Anastasakis M. et. al. [17], Li Juan Yu et. al. [3], Zadernowski R. et. al. [4].

All enzyme preparations have been studied showed a positive effect on the extraction of carotene in carrot juice in comparison with the traditional method (without treatment). Significant carotene concentration in juice was observed with enzyme preparations Vegazim M and Vegazim P-CS. Carotene amount was 5.17 and $4.83 \mathrm{mg} / 100 \mathrm{~g}$, respectively, which exceeded the control value by 1.8 and 1.7 times. These data are consistent with the results described by Li Juan Yu et al. [3], Sun Y. et al. [12], Vora H. M. et al. [15], but differs from the result reported by Demir N. et al. [11], who established the negative effect of enzymatic treatment on the content of $\beta$-carotene in carrot juice. This phenomenon can be explained on the one hand by the fact that enzymes destroy plant cell walls and increase the concentration of water in carrot juice, which means that the decrease in the carotene concentration is relative. And on the other hand it indicates a difference in the mechanism of enzymes action.

Thus, the enzyme Vegazim P-CS (pectinase), showed high efficiency in the pre-treatment of carrot pulp and was chosen for further experiment. For the effective use of this preparation, optimization of enzymatic process parameters was carried out based on the construction and analysis of the mathematical model.

The data obtained in the experiment, as well as the verification of the adequacy of the regression equation, are presented in Table 2 .

Second-order regression equation relating carrot juice yield to coded levels of the variables so developed are as follows:

$$
\begin{gathered}
Y=75,887+3,705 \cdot x_{1}+2,062 \cdot x_{2}+ \\
+1,032 \cdot x_{3}-1,942 \cdot x_{1} \cdot x_{2}-2,075 \cdot x_{1} \cdot x_{3}- \\
-0,633 \cdot x_{2} \cdot x_{3}-4,383 \cdot x_{1}^{2}-2,845 \cdot x_{2}^{2}-4,583 \cdot x_{33}^{2} .
\end{gathered}
$$

Verification using Fisher's criterion showed that the developed model is adequate and can be used for further 
Analysis of variance of the second-order model

\begin{tabular}{|c|c|}
\hline Parameter & Value \\
\hline Coefficient of determination & $R^{2}=95.8 \%$ \\
\hline Sum of variances & $\sum S^{2}(y)=95.6$ \\
\hline Maximum variance & $S_{\max }^{2}(y)=9.4$ \\
\hline Estimated value of Cochran's criterion & 0.099 \\
\hline Table value of Cochran's criterion, $\mathrm{P}=0.95$ & 0.271 \\
\hline
\end{tabular}

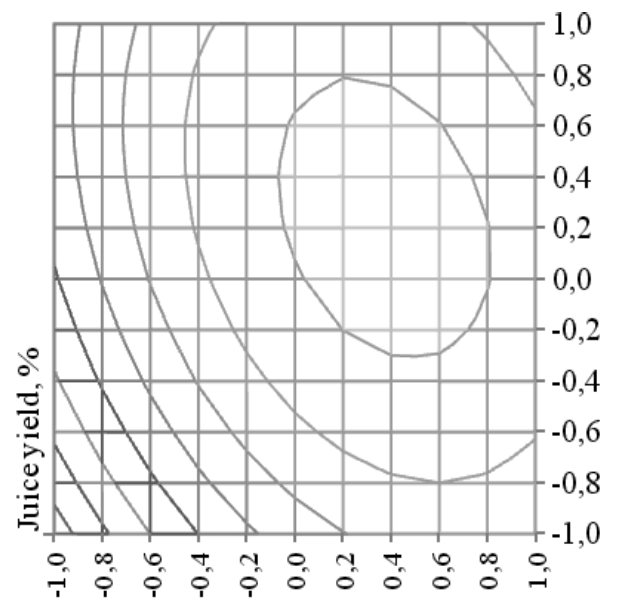

Temperature

$b$

analysis. Results of variance analysis of the model are reported in the Table 3.

Having fixed the values of one factor $\left(\mathrm{x}_{3}\right)$ at the minimum, zero and maximum levels, graphic representation of the model in the form of the surfaces was obtained (Fig. 2).

As can be seen from surfaces, the juice yield was high when enzyme concentration increased up to values of $\sim 0.3 \mathrm{ml} / 1000 \mathrm{~g}$ of carrot weight. A further increase in ratio led to a decrease in the response values due to thinning of the pulp and deterioration of recovery, which agrees with the experimental data. The enhance in temperature and incubation time greater than $65^{\circ} \mathrm{C}$ and 120 min does not further increase the juice yield.

The optimal parameters of enzymatic process were found using the "Find Solution" function in the Exsel package, the following values of the factors were determined in uncoded values: temperature $\sim 52{ }^{\circ} \mathrm{C}$, incubation time $\sim 85 \mathrm{~min}$, concentration of enzyme preparation $\sim 0.3 \mathrm{ml} / 1000 \mathrm{~g}$ of carrot weight.

\section{Conclusions}

Results of the study allow making following conclusions: enzymatic pre-treatment increases the carrot juice yield and the carotene concentration in the finished product, which is consistent with the literature data [10, 13, 14, 17]. For more effective application of selected enzyme preparations, it is necessary to optimize the enzymatic process parameters. Any optimization criterion can be selected at the discretion of manufacturer. The application of mathematical modeling makes it possible to determine the temperature, incubation time and concentration of the enzyme, which provide the maximum response.
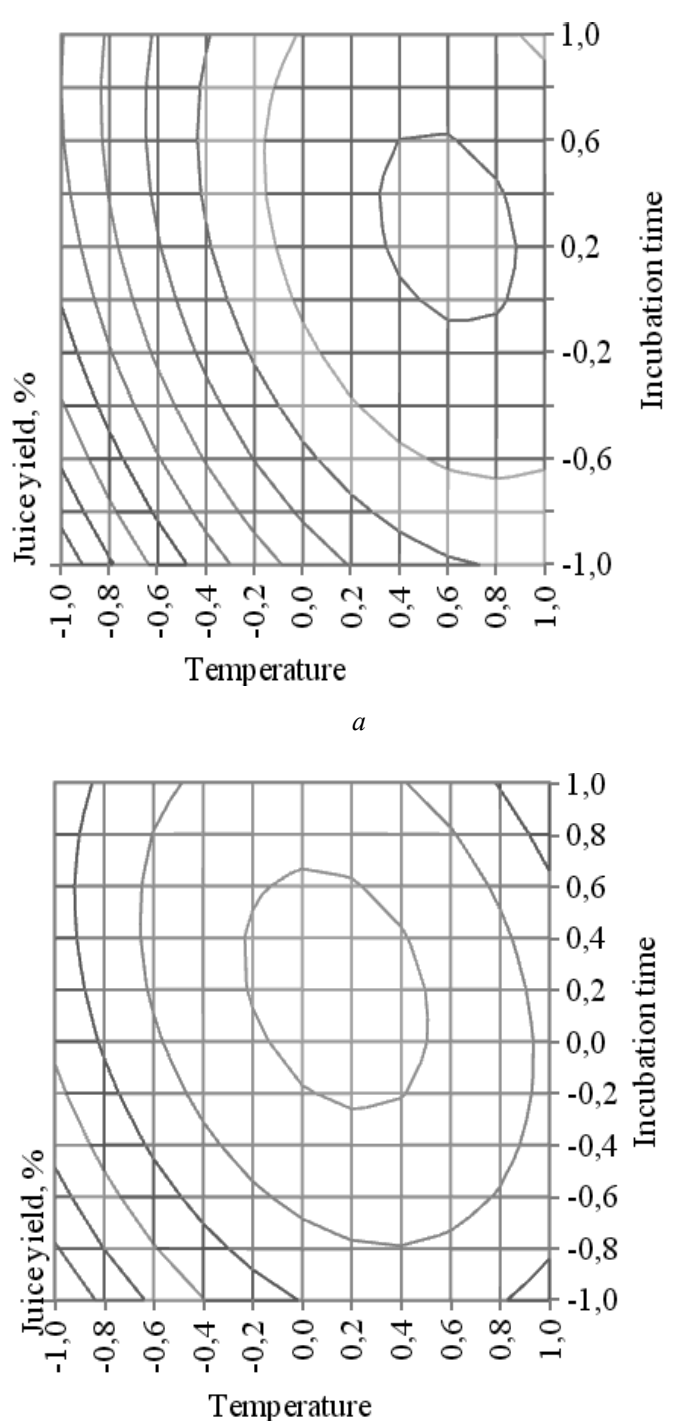

c

Fig. 2. Juice yield as affected by temperature and incubation time at three levels of concentration: $a-x_{3}=-1 ; b-x_{3}=0 ; c-x_{3}=1$

\section{References}

1. Khandare V., Walia S., Singh M., Kaur C. Black carrot (Daucus carota ssp. sativus) juice: Processing effects on antioxidant composition and color. Food and Bioproducts Processing. 2011. Vol. 89, 4. P. 482-486.

2. Gat Y., Kaur P. Optimization of process parameters for carrot juice recovery using commercial enzyme. Food Process Technology. 2015. Vol. 6, 10. P. 99. DOI: 10.4172/2157-7110. C1.030.

3. Yu L. J., Rupasinghe H. P. V. Improvement of cloud stability, yield and b-carotene content of carrot juice by process modification. Food Science and Technology International. 2013. Vol. 5. P. 399-406. http://fst.sagepub.com/content/early/2013/05 /28/1082013212455342.

4. Zadernowski R., Budrewicz G., Borowska E. U., Kaszubski W. Sok я marchwi naturalnie metny — kryteria doboru surowca oraz optymalizacji procesu technologicznego. Przem. ferment. owoc.-warz. 2003. Vol. 47, 9. P. 16-17.

5. Siddiq M., Dolan K. D., Perkins-Veazie P., Collins J. K. Effect of pectinolytic and cellulytic enzymes on the physical, chemical, and antioxidant properties of blueberry (Vaccinium corymbosum L.) juice. LWT - Food Science and Technology. 2018. Vol. 92. P. 127-132. https://doi.org/10.1016/j. lwt. 2018.02.008. 
6. Ninga K. A., Sengupta S., Jain A., Desobgo Z. S. C., Nso E. J., De S. Kinetics of enzymatic hydrolysis of pectinaceous matter in guava juice. Journal of Food Engineering. 2018. Vol. 221. P. $158-166$.

7. Weber F., Larsen L. R. Influence of fruit juice processing on anthocyanin stability. Food Research International. 2017. Vol. 100, Part 3. P. 354-365. https://doi.org/10.1016/j. foodres. 2017.06.033.

8. Dal Magro L., Dalagnol L. M. G., Manfroi V., Hertz P. F., Klein M. P., Rodrigues R. C. Synergistic effects of Pectinex Ultra Clear and Lallzyme Beta on yield and bioactive compounds extraction of Concord grape juice. $L W T$ - Food Science and Technology. 2016. Vol. 72. P. 157-165.

9. Shobinger U. Fruit and vegetable juices: scientific foundations and technologies. St.-P.: Profession, 2004. 83-90 p. (in Russian) [Шобингер У. фруктовые и овощные соки: научные основы и технологии. СПб.: Профессия, 2004. 83-90 С.]

10. Demir N., Acar J., Sarığlu K., Mutlu M. The use of commercial pectinase in fruit juice industry. Part 3: Immobilized pectinase for mash treatment. Journal of Food Engineering. 2001. Vol. 47, 4. P. 275-280.

11. Demir N., Acar J., Bahceci K. S. The effect of processing method on the characteristics of carrot juice. Journal of Food Quality. 2007. Vol. 30. P. 813-822.

12. Sun Y., Wang Z., Wu J., Chen F., Liao X., Hu X. Optimising enzymatic maceration in pretreatment of carrot juice concentrate by response surface methodology. International Journal of Food Science and Technology. 2006. 41. P. 1082-1089.

13. Sharma A. K., Sarkar B. C., Sharma H. K. Optimization of enzymatic process parameters for increased juice yield from carrot (Daucus carota L.) using response surface methodology. European Food Research Technology. 2005. Vol. 221. P. 106112.

14. Liao H., Sun Y., Ni Y., Liao X., Hu X., Wu J., Chen F. The effect of enzymatic mash treatment, pressing, centrifugation, homogenization, deaeration, sterilization and storage on carrot juice.

\section{Information about authors}

Zelenkova Elena N.

assistant of Department of physico-chemical methods of products certification BSTU, Republic of Belarus, 220006,

Minsk, Sverdlova St., 13a, elena.taras@mail.ru

\section{Yegorova Zinaida E.}

Ph. D., Associate Professor of Department of physico-chemical methods of products certification BSTU, Republic of Belarus, 220006, Minsk, Sverdlova St., 13a,

egorovaze@tut.by
Journal of Food Process Engineering. 2007. Vol. 30, 4. P. 421435.

15. Vora H. M., Kyle W. S. A., Small D. M. Activity, localisation and thermal inactivation of deteriorative enzymes in Australian carrot (Daucus carota L.) varieties. Journal of the Science of Food and Agriculture. 1999. Vol. 79. P. 1129-1135.

16. Chadha R., Kumghar B. K., Sarkar B. C. Enzymatic hydrolysis of carrot juice recovery. Journal of Food Science and Technology. 2003. Vol. 40. P. 35-39.

17. Anastasakis M., Lindamood J. B., Chism G. W., Hansen P. M. T. Enzymatic hydrolysis of carrot for extraction of a cloud-stable juice. Food Hydrocolloids. 1987. Vol. 1, 3. P. 247-261.

18. Çinar İnci Effects of cellulase and pectinase concentrations on the colour yield of enzyme extracted plant carotenoids. Process Biochemistry. 2005. Vol. 40, 2. P. 945-949.

19. Ma T., Tian C., Luo J., Sun X., Quan M., Zhan J. Influence of technical processing units on the $\alpha$-carotene, $\beta$-carotene and lutein contents of carrot (Daucus carrot L.) juice. Journal of Functional Foods. 2015. 16. P. 104-113.

20. Ma T., Tian C., Luo J., Zhou R., Sun X., Ma J. Influence of technical processing units on polyphenols and antioxidant capacity of carrot (Daucus carrot L.) juice. Food Chemistry. 2014. Vol. 159. P. 1637-1644.

21. Zhao C., Li S., Li S., Song G., Yu L., Zhang H. Extraction optimization approach to improve accessibility of functional fraction based on combination of total polyphenol, chromatographic profiling and antioxidant activity evaluation: Pyracantha fortuneana fruit as an example. Journal of Functional Foods. 2013. Vol. 5. P. 715-728.

22. Jang M., Jeong S., Cho S., Yang H., Yoon D., Kim J., Park K. Improvement in the anti-inflammatory activity ofguava (Psidium guajava L.) leaf extracts through optimization of extraction conditions. Journal of Functional Foods. 2014. Vol. 10. P. 161168.

\section{Сведения об авторах}

\section{Зеленкова Елена Николаевна}

ассистент кафедры физико-химических методов сертификации продукции БГТУ, Республика Беларусь, 220006,

г. Минск, ул. Свердлова, 13a, elena.taras@mail.ru

\section{Егорова Зинаида Евгеньевна}

к. т. н., доцент кафедры физико-химических методов сертификации продукции БГТУ, Республика Беларусь, 220006, г. Минск, ул. Свердлова, 13а, egorovaze@tut.by 